\title{
ポリカルボシラン繊維の熱酸化不融化の速度論
}

\author{
下尾聰夫・杉本雅樹*・岡村清人 \\ 大阪府立大学工学部金属工学科, 591 堺市百舌鳥梅町 4 丁 804 \\ *大阪府立大学大学院生, 591 堺市百舌鳥梅町 4 丁 804
}

\section{Kinetics of Curing of Polycarbosilane Fiber by Oxidation Treatment}

\author{
Toshio SHIMOO, Masaki SUGIMOTO* and Kiyohito OKAMURA \\ Department of Metallurgical Engineering, College of Engineering, University of Osaka Prefecture, 4-804, Mozu-Umemachi, Sakai-shi \\ ${ }^{*}$ Graduate Student, University of Osaka Prefecture, 4-804, Mozu-Umemachi, Sakai-shi 591
}

[Received December 25, 1990; Accepted February 20, 1991]

\begin{abstract}
The mechanism of curing of polycarbosilane (PCS) fiber has been investigated. Polycarbosilane has been melt-spun to fibers in the diameter range of $21-113 \mu \mathrm{m}$. The rate of curing of PCS fiber was measured with a thermo-balance in $\mathrm{Ar}-\mathrm{O}_{2}$ gas mixtures with $5-100 \mathrm{kPa}$ $\mathrm{O}_{2}$ at temperatures from $413 \mathrm{~K}$ to $463 \mathrm{~K}$. The rate of curing increased with increasing curing temperature and $p_{0_{2}}$, and with decreasing fiber diameter. The fiber melted to agglomerate in a mass, depending on the curing temperature, $p_{\mathrm{O}_{2}}$ in $\mathrm{Ar}-\mathrm{O}_{2}$ gas mixtures and the size of fibers. A cured layer, through which oxygen molecules can advance and reach the reaction interface, was formed around the fiber. The reaction interface receded towards the center of the fiber as the curing progressed. In the early stage of curing, the kinetics followed the contracting-disc formula: $1-(1-X)^{1 / 2}$ $=k t$. The apparent activation energy was $87.7 \mathrm{~kJ} / \mathrm{mol}$. The rate constant $k$ was proportional to $p_{0_{2}}$ and was inversely proportional to the diameter of the fiber. It is considered that the curing of PCS fiber is controlled by the interfacial reaction. In the late stage of the reaction, curing is controlled by the diffusion of oxygen through the reaction layer.
\end{abstract}

Key-words: Polycarbosilane fiber, Oxidation treatment, Curing kinetics, Thermogravimetry, Reaction mechanism, Ratedetermining step

\section{1. 緒 言}

炭化ケイ素系緘維の最大の弱点は $1573 \mathrm{~K}$ 以上の温度で 熱分解が起こり，瀻維の機械的強度が急激に低下すること である ${ }^{1,2)}$. 最近注目されているセラミックス複合材料の 強化材としての使用の場合でも，この熱分解は克服すべき 課題である．著者らは各種炭化ケイ素系緘維の熱分解の反

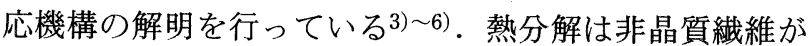
$\mathrm{SiO}$ と $\mathrm{CO}$ を発生しながら $\beta-\mathrm{SiC}$ へ結晶化する反応であ ることを明らかにした．また分解速度は瀻維中酸素濃度と 密接に関係することを示した6).

市販の炭化ケイ素系繊維は，(1)有機ケイ素ポリマーの溶 融紡系，(2)繊維の熱酸化不融化，及び(3)焼成の工程を経て 製造される7)。(2)は溶融紡系した繊維を融着させずに焼成 し, 無機化して炭化ケイ素系繊維を得るための重要な工程
である，不融化は酸素による架橋反応であるから，瀻維中 に必然的に酸素が導入される ${ }^{8}$. 最終製品の炭化ケイ素系 繊維の熱分解を抑制するためには，不融化処理の際に導入 される瀻維中酸素濃度を適正な水準に制御することが不可 欠である. そのためには熱酸化不融化の速度及び反応機構 を明らかにする必要がある。

不融化の際に進行する反応あるいは不融化処理後の繊維 のキャラクタリゼーションを対象とした研究はかなり行わ れている7) 13). しかし，不融化過程の速度論的な検討は

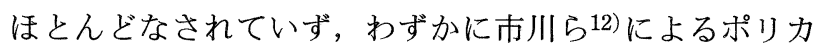
ルボシラン粉末の酸化反応に関する研究があるにすぎない のが現状である. 本研究ではポリカルボシランを溶融紡糸 して得た緎維を用いて, 等温下での熱酸化不融化の速度を 熱天秤によって測定した. 不融化温度, 雾囲気の酸素分圧 及び䋐維径の影響について詳細に調べ，熱酸化不融化の反 応機構及び律速段階の解明を行った。

\section{2. 実験方法}

供試材のポリカルボシラン繊維（以下では PCS 繊維と 称す）は信越化学製のポリカルボシランを $\mathrm{Ar}$ 雾囲気下, $573 \mathrm{~K} \sim 603 \mathrm{~K}$ の温度域で溶融紡系を行って得たものであ る. 紡系速度を変化させることによって, 直径21１13 $\mu \mathrm{m}$ の繊維を作製した。

PCS 繊維の熱酸化不融化機構を解明するために下記の 2 種類の実験を行った.

\section{1 等温加熱による PCS 繊維の酸化速度の測定}

$1 \mathrm{~g}$ の繊維を装入した炭素るつぼを自動天秤（秤量 : $100 \mathrm{~g}$, 感量 : $0.1 \mathrm{mg}$ ）に接続後, 所定の温度に調整した カンタル炬の均熱帯に吊した．以後，PCS 䋐維の熱酸化 不融化に伴う質量増加量を連続測定した。炉雾囲気のガス は全圧 $100 \mathrm{kPa}$ の $\mathrm{Ar}-\mathrm{O}_{2}$ 混合ガスであり, $p_{\mathrm{O}_{2}}=5 \sim 100$ $\mathrm{kPa}$ と変化させた．ガスは $1.67 \times 10^{-5} \mathrm{~m}^{3} / \mathrm{s}$ の流量で炉底 から導入した．なお，ガスが炭素るつぼ内を十分に流通す るように，るつほの底面及び側面に多数の穴を設けた。な お，本実験温度域では炭素るつほの酸化減量は認められな かった.

\section{2 連続加熱による PCS 緎維の酸化量の測定}

純酸素雾囲気中で $40 \mathrm{~K} / \mathrm{h}$ の加熱速度で昇温して，直径 
$113 \mu \mathrm{m}$ の PCS 繊維の熱酸化不融化処理を行った. 423 $\mathrm{K} \sim 483 \mathrm{~K}$ の各不融化温度に $1.8 \mathrm{ks}$ 保持して冷却した. 不 融化処理前後の繊維の質量を秤量することによって，繊維 の酸化量を求めた。

$443 \mathrm{~K}$ 及び $483 \mathrm{~K}$ での不融化処理によって得られた酸化 状態が異なる 2 種類の PCS 繊維を用いて, 繊維の酸化層 の成長状況を観察した。

まず繊維を $\mathrm{Ar}$ 雲囲気中で1473 K まで加熱して焼成処 理を行った．その後 $\mathrm{Ar}$ 䨌囲気中で1973 K まで加熱して， 繊維を熱分解させた。この繊維の破断面を走査型電子顕微 鏡（SEM）によって観察した。すなわち繊維に含まれる 酸素量によって熱分解の進行に基づく $\beta-\mathrm{SiC}$ 結晶粒の成長 状態が異なること6)を利用した。

\section{3. 結 果}

\section{1 温度の影響}

$413 \mathrm{~K} \sim 463 \mathrm{~K}$ の各温度における熱酸化不融化による PCS 繊維の質量増加曲線を図 1 に示す。ここに $\Delta W$ は熱 天秤で測定した質量増加量であり， $W_{0}$ は繊維の初期質量 である．実験に供したPCS 繊維の繊維径は $113 \mu \mathrm{m}$ であ る.また雾囲気は $p_{\mathrm{O}_{2}}=20 \mathrm{kPa}, p_{\mathrm{Ar}}=80 \mathrm{kPa}(100 \mathrm{kPa} \fallingdotseq 1$ atm）である．熱酸化処理によって質量増加が生じるのは PCS 繊維中に酸素が導入されるためであるＰCS 繊維の 不融化速度は質量増加速度で評価できる．反応開始直後で は不融化速度に対する温度の影響が認められない。試料が 所定の実験温度に昇温して熱酸化が定常的に進行するよう になると，不融化速度に温度の影響が現れる．当然ながら 高温であるほど，不融化速度が大きくなる． $463 \mathrm{~K}$ の曲線 の $2 \mathrm{ks}$ 以後において, 不融化速度の急増が頻繁に認めら れる．これは後述するように繊維温度が暴走して，酸化が 加速されるためである。最終的には PCS が溶融して, 繊 維が融着していた。 $463 \mathrm{~K}$ 以上の温度では繊維の融着及び 燃焼によって不融化速度が測定できなかった。

\section{2 酸素分圧及び繊維径の影響}

$423 \mathrm{~K}$ において雾囲気の酸素分圧を $p_{\mathrm{O}_{2}}=5 \sim 100 \mathrm{kPa}$ と
変化させて, PCS 繊維の不融化挙動を調べた。緎維径が $d=113 \mu \mathrm{m}$ 及び $65 \mu \mathrm{m}$ の場合についての結果をそれぞれ 図 2 及び図 3 に示す. いずれの場合にも $p_{\mathrm{O}_{2}}$ の増加ととも に不融化が促進されている．なお $d=65 \mu \mathrm{m}$ と細い繊維で は $p_{\mathrm{O}_{2}}>20 \mathrm{kPa}$ で融着・燃焼が起こり，不融化速度が測定 できなかった．ちなみに図 3 に示した $p_{\mathrm{O}_{2}}=30 \mathrm{kPa}$ の場合 には，約 $1 \mathrm{ks}$ で急激な質量増加が生じている．後に検討 するように，不融化によって発生する熱が繊維中に蓄積さ れて，不融化温度が暴走するためである。

図 2 と図 3 との比較から明らかなように，同じ $p_{\mathrm{O}_{2}}$ で は, 細い繊維の不融化速度が大きい。

\section{3 連続加熱方式による PCS 繊維の熱酸化}

これまで等温加熱による PCS 繊維の不融化速度を測定 してきた.しかし工業的には PCS 繊維の不融化処理は室 温から不融化温度まで連続加熱することによって行われて いる．そこで実験方法の 2.2 節に記した実験を行って，繊 維の質量増加率と不融化温度の関係を求めた。その結果を 図 4 に示す。なお繊維の質量増加率 $100 \cdot \Delta W / W_{0}$ の值は 纎維中の酸素濃度 (mass $\% \mathrm{O})$ 増加量にほぼ一致する ${ }^{12)}$ $463 \mathrm{~K}$ までは不融化温度が高くなるにつれて, 質量増加率 が緩やかに大きくなっている. $463 \mathrm{~K}$ と $473 \mathrm{~K}$ との間で,



Fig. 4. Mass gain with curing of PCS fiber $(d / \mu \mathrm{m}=113)$ heated continuously at $40 \mathrm{~K} / \mathrm{h}$ and hold at various curing temperature for $1.8 \mathrm{ks}$ in a pure oxygen atmosphere.

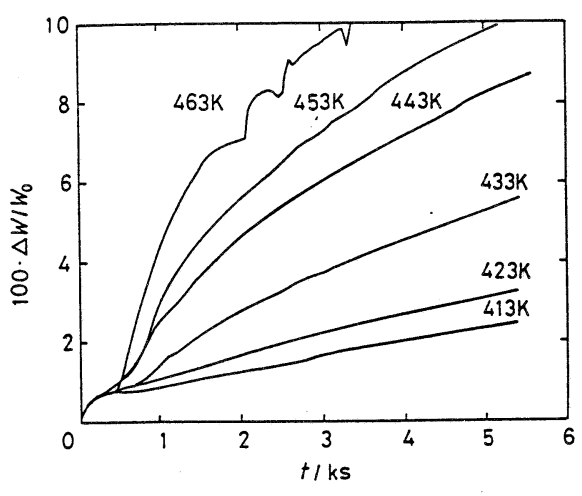

Fig. 1

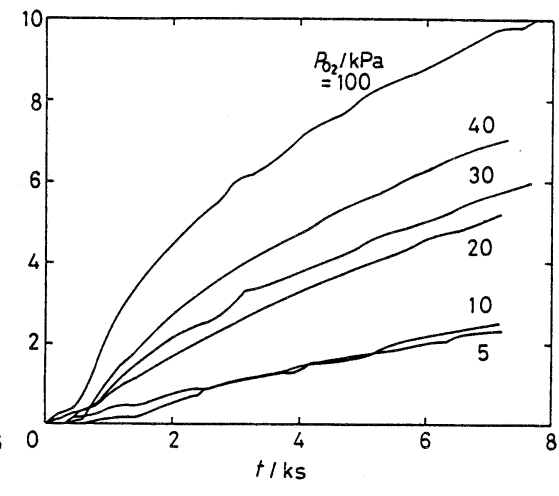

Fig. 2

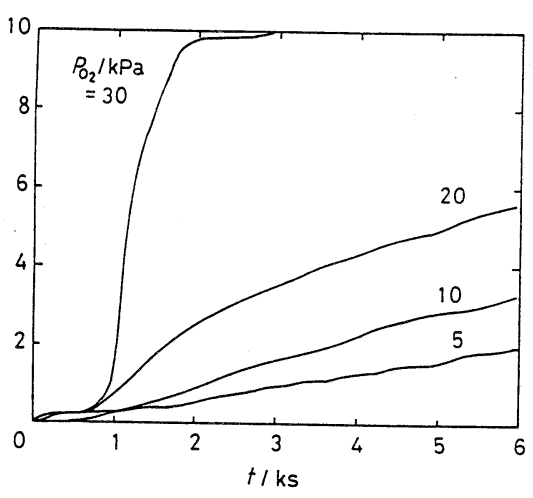

Fig. 3

Fig. 1. Mass gain with curing of PCS fibers $(d / \mu \mathrm{m}=113)$ heated isothermally at various temperatures in $80 \% \mathrm{Ar}-20 \% \mathrm{O}_{2}$ gas mixture.

Fig. 2. Effect of $p_{\mathrm{O}_{2}}$ in $\mathrm{Ar}-\mathrm{O}_{2}$ gas mixture on mass gain with curing of PCS fiber $(d / \mu \mathrm{m}=113)$ heated isothermally at $423 \mathrm{~K}$.

Fig. 3. Effect of $p_{\mathrm{O}_{2}}$ in $\mathrm{Ar}-\mathrm{O}_{2}$ gas mixture on mass gain with curing of PCS fiber $(d / \mu \mathrm{m}=65)$ heated isothermally at $423 \mathrm{~K}$. 
質量増加率は約 3 倍へと急増している。不融化温度の暴 走が起こり始めていると推定される。しかし等温加熱の場 合のように繊維は融着していない。

\subsection{PCS 繊維に形成される酸化層の観察}

図 4 から明らかなように，443 K 及び $483 \mathrm{~K}$ で不融化処 理を行った繊維の質量増加率（酸素濃度に相当する）はそ れぞれ $4.5 \%$ 及び28.9\%と著しく異なる。これら繊維を $1473 \mathrm{~K}$ で焼成した後，更に1973 K の高温へ加熱した。高 温では酸素を含む非晶質の炭化ケイ素瀻維は熱分解する が，これは $\mathrm{SiO}$ と $\mathrm{CO}$ を発生して $\beta$ - $\mathrm{SiC} へ と$ 結晶化する 過程である3) -6)。

$$
\mathrm{SiC}_{1+X} \mathrm{O}_{Y} \text { (amorphous) } \rightarrow \beta-\mathrm{SiC}+\mathrm{SiO}(\mathrm{g})+\mathrm{CO}(\mathrm{g})
$$

高酸素濃度の繊維は分解が速やかであり， $\mathrm{SiC}$ 結晶粒の成 長速度も大きい6)。一方，酸素を含んでいない PCSを高 温で焼成すると，(2)式の反応が起こる14).

$\mathrm{SiC}_{1+X}$ (amorphous) $\rightarrow \beta$ - $\mathrm{SiC}+\mathrm{C}$ (amorphous) (2) このように酸素の有無によって反応機構が相違するため に，焼成処理後の織維中 $\mathrm{SiC}$ の粒成長の度合いが異なる。 したがって繊維断面の結晶粒の成長状況を観察することに よって，繊維中への酸素の浸透状沉が把握できる。

繊維断面の走查型電子顕微鏡 (SEM) 写真を図 5 に示 す. $443 \mathrm{~K}$ 不融化処理では，絨維表面 $(\mathrm{A})$ 及び表面近くの 薄い層のみ $(\mathrm{B})$ で結晶粒が成長・粗大化しているにすぎな い. 中心部 $(\mathrm{C})$ の結晶粒は小さく, $\beta-\mathrm{SiC}$ 結晶粒同士の食


Fig. 5. SEM photographs of PCS fibers decomposed at $1973 \mathrm{~K}$ after curing at $443 \mathrm{~K}$ and $483 \mathrm{~K}$ in an oxygen atmosphere and heating at $1473 \mathrm{~K}$ in an argon atmosphere.

Curing temperature $=443 \mathrm{~K}, 100 \cdot \Delta W / W_{0}=4.5:$ (A) surface,

(B) cross section and (C) center of fiber.

Curing temperature $=483 \mathrm{~K}, 100 \cdot \Delta W / W_{0}=28.9$ : (D) surface,

(E) cross section and $(F)$ center of fiber.

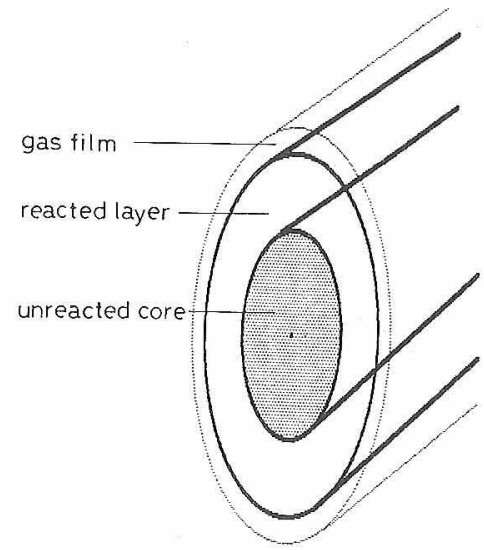

Fig. 6. Schematic representation of curing of PCS fiber.

い合いによる粗大化現象がほとんど起こっていない。これ は織維の表面近くの層で(1)式の反応が，また内部で(2) 式の反応が進行するためと推定される. 一方 $483 \mathrm{~K}$ 不融化 処理の高酸素濃度繊維では，断面全体に扝いて熱分解によ る結晶粒の粗大化が認められる $(\mathrm{D}) ，(\mathrm{E}) ，(\mathrm{~F})$ 。これは繊 維表面及び内部の全域に扔いて，(1)式の熱分解反応が進 行したことを示唆する。なお繊維表面の粒子が $443 \mathrm{~K}$ 不融 化処理の場合より細かいことは注目される。この理由につ いては判然としない。これらの繊維を粉末にしてX線回 折を行った. $483 \mathrm{~K}$ 不融化処理の力が $\beta$-SiC の回折パター ンがシャープであり，SEM 観察と対応することがわかっ た。 以上の結果より, 反応界面が繊維断面の外径と相似を 保ちながら不融化が進行する（図6）と考えられる.

\section{1 速度解析}

\section{4. 考 察}

熱分解後の繊維の断面の SEM 観察結果から，PCS 繊 維の熱酸化不融化の進行状況は模式的に図 6 に示される. すなわち不融化は次の過程を経て進行すると考えられる。

(1) 繊維周囲のガス境膜を通しての酸素の表面への移 動,

(2) 繊維表面から反応層を通っての未反応芯表面への酸 素の移動,

(3) 反応界面に扔ける化学反応。

図 6 に示すような円筒状の繊維への適用を検討する。以 下に各過程が律速段階の場合について考察する.

(1) ガス境膜内桩散律速の場合

繊維の不融化速度 $n / \mathrm{mol} \cdot \mathrm{s}^{-1}$ は (3) 式で与えられる。

$$
n=2 \pi r_{0} l k_{\mathrm{g}}\left(p_{\mathrm{O}_{2}}-p_{\mathrm{O}_{2}}{ }^{i}\right) / R T
$$

ここに, $r_{0}$ 及び $l: \operatorname{PCS}$ 緎維の半径及び長さ

$$
k_{\mathrm{g}}: \text { 物質移動係数 }
$$

$p_{\mathrm{O}_{2}}$ 及び $p_{\mathrm{O}_{2}{ }^{i}}:$ ガス本体中及び緎維表面での酸素分圧

$$
R: \text { 気体定数 }
$$

$p_{\mathrm{O}_{2}}$ と比較して $p_{\mathrm{O}_{2}}{ }^{i}$ は小さいので無視し，末た(4)式の関係 を用いて変形すると，(5)及び(6)式が得られる。

$$
\begin{aligned}
n & =\mathrm{d}\left\{\left(\pi r_{0}{ }^{2} l-\pi r_{i}^{2} l\right) d_{0}\right\} / \mathrm{d} t \\
& =-2 \pi r_{i} l d_{0}\left(\mathrm{~d} r_{i} / \mathrm{d} t\right)
\end{aligned}
$$




$$
\begin{aligned}
& X=k^{\prime} t \\
& k^{\prime}=2 k_{\mathrm{g}} p_{\mathrm{O}_{2}} / R T r_{0} d_{\mathrm{O}}
\end{aligned}
$$

ここに， $r_{i}$ は緎維中未反応芯の半径である， $d_{0}$ は酸化不 融化した繊維中の酸素濃度 $\left(\mathrm{mol} / \mathrm{m}^{3}\right)$ である. また $X は$ 反応率であり，(7)式で定義される.

$$
X=1-\left(r_{i} / r_{0}\right)^{2}
$$

(5)及び $(6)$ 式によると，雲囲気の $p_{\mathrm{O}_{2}}$ が大きいほど，また 繊維径 $r_{0}$ が小さいほど不融化が促進されることがわかる. これは図 1 及び図 3 に示した本実験結果とほぼ対応して いる. しかし不融化による PCS 繊維の質量増加の経時変 化が曲線となることは (5) 式の直線則を満足していない. 反応初期に拈いて，(5)式の直線則を近似適用して速度を 求めた。なお速度は $\mathrm{d}\left(\Delta W / W_{0}\right) / \mathrm{d} t$ で評価した。図 7 は $\mathrm{d}\left(\Delta W / W_{0}\right) / \mathrm{d} t$ のアレニウス・プロットを示す．見掛けの 活性化エネルギーとして $94.2 \mathrm{~kJ} / \mathrm{mol}$ が得られた. 同図中 に粉末のポリカルボシランを空気中で酸化した市川等の結 果12) も併示した. 実験条件が相違するので単純に比較 できないとは言え，見掛けの活性化エネルギーが85.4 $\mathrm{kJ} / \mathrm{mol}$ であり, 本実験值とほぼ等しいことは興味ある結果 である。これは反応の機構及び律速過程が同じであること を示唆する.

ところで境膜説によると, 物質移動係数 $k_{\mathrm{g}}$ は (8) 式で示 される.

$$
k_{\mathrm{g}}=D / \delta
$$

ここに, $D:$ 気体中酸素の拡散係数

$$
\delta: \text { ガス境膜の厚さ }
$$

一般に気体の拡散係数は $T^{1.5}$ あるいは $T^{1.8}$ に比例する ${ }^{15)}$. この温度依存性と(6) 及び(8) 式の関係から $413 \mathrm{~K} \sim 463 \mathrm{~K}$ での活性化エネルギーを見積もると， $1.8 \sim 2.9 \mathrm{~kJ} / \mathrm{mol}$ と なる.この值と比較して上記の本実験值は著しく大きい. 以上の検討より，(1)の過程が律速段階ではないと結論でき る.

\section{（2） 反応層における拡散律速}

$\mathrm{PCS}$ 繊維のような円筒形試料の側面から内部へ拡散す る場合，この過程を律速段階とすると，(9)式の界面減少 型拡散律速速度式が成立する ${ }^{16)}$.

$$
(1-X) \ln (1-X)+X=k^{\prime} t
$$

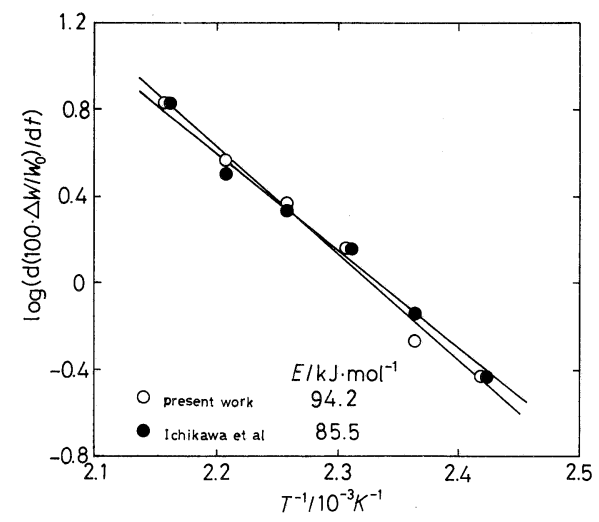

Fig. 7. Temperature dependence of initial rate of curing, $\mathrm{d}\left(\Delta W / W_{0}\right) / \mathrm{d} t$.

\section{ここに， $k^{\prime}$ は速度定数である.}

(10)式によって, PCS 繊維の質量増加量 $\Delta W$ から $X$ を 計算できる.

$$
X=\Delta W / \Delta W^{\mathrm{f}}
$$

$\Delta W^{\mathrm{f}}$ は不融化終了時（質量増加がなくなった時点）にお ける質量増加量である.

$\Delta W^{\mathrm{f}}$ を求めるために， $423 \mathrm{~K}, p_{\mathrm{O}_{2}}=20 \mathrm{kPa}$ において長 時間の不融化実験を行った. $\Delta W / W_{0}$ の経時変化を図 8 に 示す.これより $X$ の経時変化を求め, (9)式の速度式を啇 用した結果を図 8 に併記する。本実験で対象とする反応 前期（ $t \leqq 6 \mathrm{ks}, X \leqq 0.55)$ では，直線関係が成立しないこ とより, (2)の過程が不融化反応の律速過程ではない. しか し反応後期になると， $0.55 \leqq X \leqq 0.70$ の間で良好な直線性 が得られる．これは不融化された反応層が厚くなり拡散距 離が長くなるので, 酸素の拡散が困難となるためと考えら れる。

（3）界面反応律速

界面化学反応として一次反応を仮定し，また逆反応が無 視できることを考慮すると，その速度 $n / \mathrm{mol} \cdot \mathrm{s}^{-1}$ は(11) 式で表される.

$$
n=2 \pi r_{i} l k_{\mathrm{r}} p_{\mathrm{O}_{2}} / R T
$$

ここに， $k_{\mathrm{r}}$ は反応速度定数である.

(4) 及び(7) 式と組み合わせて変形することによって, (11)式から次式が得られる.

$$
\begin{aligned}
& 1-(1-X)^{1 / 2}=k^{\prime \prime} t \\
& k^{\prime \prime}=k_{\mathrm{r}} p_{\mathrm{O}_{2}} / r_{0} d_{\mathrm{O}} R T
\end{aligned}
$$

(12)式の速度式の適用結果を図 8 に併示した。 反応前期 では, 良好な直線関係が成立する。応の後半 $(X \leqq 0.55)$ になると，プロットは下方へ湾曲する。この 領域では，上記のごとく(9)式の拡散律速式が成立する. 反応の前 ·後期で PCS 繊維の不融化の律速段階が変化す ると推定される．すなわち不融化層が薄い反応前期では， この層を通しての酸素の拡散が容易で界面反応速度＜拡散 速度である. 反応後期で不融化層が厚くなると, 界面反応 速度>拡散速度となる。本実験時間内では, PCS 繊維の 熱酸化不融化は主に界面反応律速域にある。そこで(12) 式の界面反応律速式を用いて, 実験結果についての検討を

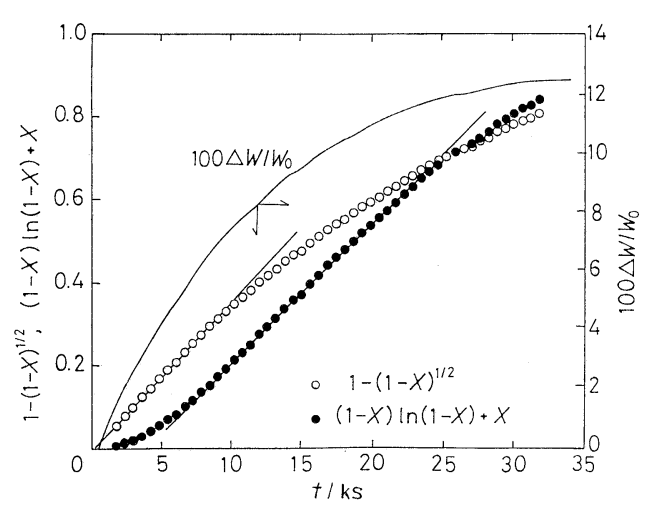

Fig. 8. Mass gain with curing of PCS fibre $(d / \mu \mathrm{m}=113), 1-$ $(1-X)^{1 / 2}$ vs. time and $(1-X) \ln (1-X)+X$ vs. time plots in $80 \% \mathrm{Ar}-20 \% \mathrm{O}_{2}$ gas mixture at $453 \mathrm{~K}$. 


\section{以下に行う。}

ここで問題となるのは $X$ を求める際に必要となる $\Delta W^{\mathrm{f}}$ の評価である. (12)式を満足するように, 試行錯誤法に よって $\Delta W^{\mathrm{f}}$ の值を決定した. $453 \mathrm{~K}$ の $\Delta W^{\mathrm{f}}$ の推定值は 図 8 で求めた測定值とほぼ一致した。また，このように して本実験結果を処理しても，以下に示すように矛盾する 結果は得られなかった。

図 1 の結果に対して(12)式を適用したのが図 9 である. 反応初期を除いて良好な直線関係が成立する. 直線の勾配 より速度定数 $k^{\prime \prime}$ が求まる。（13) 式を変形して，(14)式を 得る。

$$
k=k^{\prime \prime} T=k_{\mathrm{r}} p_{\mathrm{O}_{2}} / r_{0} d_{\mathrm{O}} R
$$

$k$ の值を用いて, 温度依存性を検討した. 図10は $k$ のアレ ニウス・プロットを示す。プロットは直線関係を良く満足 している.これより見掛けの活性化エネルギーとして $87.7 \mathrm{~kJ} / \mathrm{mol}$ が得られた。 この值は有機物が関与する反応 の活性化エネルギーとして妥当な大きさである17).

図11は速度定数 $k^{\prime \prime}$ と雲囲気の酸素分圧 $p_{\mathrm{O}_{2}}$ との関係を示 す. $k^{\prime \prime} \leqq 0.06 て ゙ は ， k^{\prime \prime}$ と $p_{\mathrm{O}_{2}}$ の間に比例関係が成立してい

る. 最小自乗法によって次の関係式が得られた。

$$
\begin{array}{ll}
d / \mu \mathrm{m}=65 & k^{\prime \prime} / \mathrm{ks}^{-1}=27.7 \times p_{\mathrm{O}_{2}} / \mathrm{MPa} \\
d / \mu \mathrm{m}=113 & k^{\prime \prime} / \mathrm{ks}^{-1}=15.6 \times p_{\mathrm{O}_{2}} / \mathrm{MPa}
\end{array}
$$

これは(13)式の関係と良く対応する． $p_{\mathrm{O}_{2}}$ を大きくしても， $k^{\prime \prime}$ は 0.06 以上にならない。これは $p_{\mathrm{O}_{2}}$ の増大によって酸化

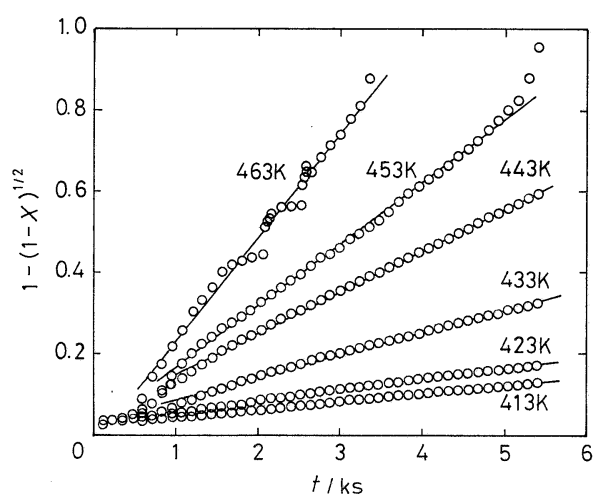

Fig. 9. Application of rate Equation (12) to data shown in Fig. 1.

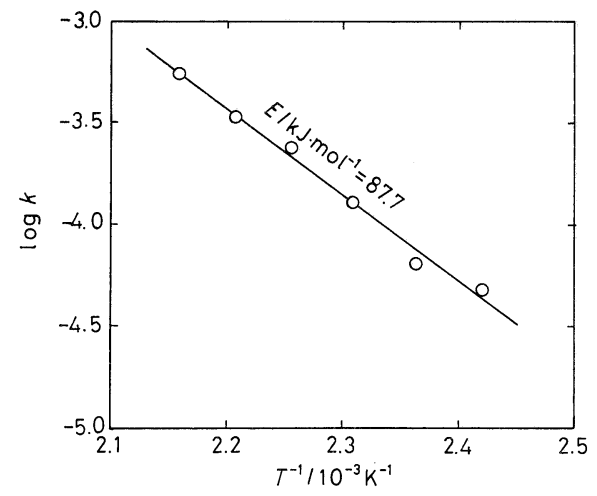

Fig. 10. Arrhenius plots of rate constant $k$.

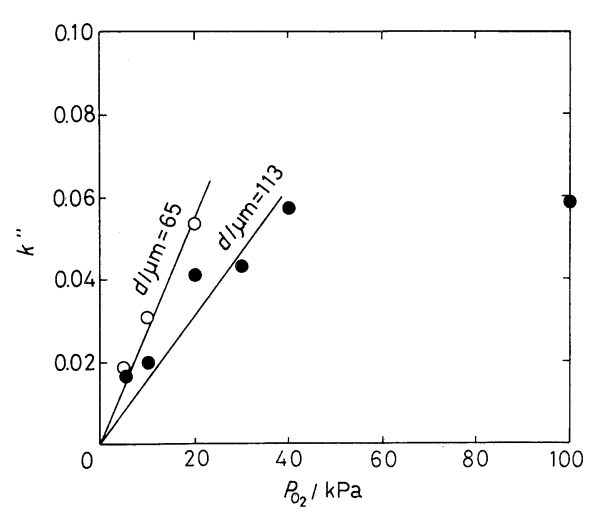

Fig. 11. Relation between rate constant $k^{\prime \prime}$ and $p_{\mathrm{O}_{2}}$.

が促進されると温度の暴走が起こり, 繊維の融着あるいは 燃焼が進行するためである. とくに $d=65 \mu \mathrm{m}$ と繊維径が 細い場合には， $p_{\mathrm{O}_{2}}$ が20 kPa を越えると繊維が燃焼して酸 化速度が測定できなかった. また(15) と(16)式の比較よ り明らかなように, 同じ $p_{\mathrm{O}_{2}}$ では $k^{\prime \prime}$ の值は細い繊維の方が 大きくなっている．この結果も(13)式の関係を良く満足 している.

\subsection{PCS 繊維の融着及び燃焼}

前述のごとく, 熱酸化不融化の処理条件によっては $\mathrm{PCS}$ 繊維の融着あるいは燃焼が起こる.これは不融化速 度が大きい条件（高い不融化温度, 高い酸素分圧及び細い 繊維径）が該当する. $20 \mu \mathrm{m}$ の細い繊維では， $453 \mathrm{~K}$, $p_{\mathrm{O}_{2}} \geqq 50 \mathrm{kPa}$ において繊維が完全に燃焼・消隇した。 また $65 \mu \mathrm{m}$ の繊維でも, $423 \mathrm{~K}, p_{\mathrm{O}_{2}}=20 \mathrm{kPa}$ においてほとんど の場合に繊維が融着して塊状化した. 一方 $100 \mu \mathrm{m}$ の太い 繊維では, $463 \mathrm{~K}, p_{\mathrm{O}_{2}}=20 \mathrm{kPa}$ 及び $423 \mathrm{~K}, p_{\mathrm{O}_{2}}=100 \mathrm{kPa}$ においても繊維の融着が起こっていない.

炭化ケイ素系繊維を製造する場合, PCS 繊維の熱酸化 不融化処理工程における融着及び燃焼は重要な問題であ る.上記のごとく，適正な不融化処理を行うためには温度， 雲团気の $p_{\mathrm{O}_{2}}$ 及び緎維径に制限があることがわかる. 本実 験では所定温度の不融化処理炉中にいきなり繊維を装入 し, 熱酸化不融化処理を行った。実際の不融化工程は緩や かに連続加熱されるので，融着・燃焼が起こる条件がかな り緩和されると考えられる.

PCS の融点は $506 \mathrm{~K}$ である．本実験温度は融点以下で あるにかかわらず，PCS 緎維の融着・燃焼が生じている. これは下記のごとく,繊維からの揮散成分の酸化燃焼によっ て繊維温度が PCS の融点以上になるためと推定される.

約 $373 \mathrm{~K}$ から PCS 繊維の不融化反応が進行する7)。す なわち(17)及び(18)式の架橋反応によって, 繊維中に SiO-Si 結合が形成される7).

$$
\begin{aligned}
& \equiv \mathrm{SiH}+\mathrm{HSi} \equiv+\mathrm{O}_{2} \rightarrow \equiv \mathrm{Si}-\mathrm{O}-\mathrm{Si} \equiv+\mathrm{H}_{2} \mathrm{O} \\
& \equiv \mathrm{SiOH}+\mathrm{HOSi} \equiv \rightarrow \equiv \mathrm{Si}-\mathrm{O}-\mathrm{Si} \equiv+\mathrm{H}_{2} \mathrm{O}
\end{aligned}
$$

この反応は発熱反応である13)。 また不融化の際に水素も 生成する13)ので, 場合によっては水素の酸化による発熱 も起こる．繊維からの熱の除去が不十分な場合には，繊維 
の温度が上昇する．その結果，PCS が溶融して繊維同士 が融着する.

ところで極端な場合には, 繊維が酸化燃焼して消隇する 場合があった。これは揮発成分の燃焼によって, 温度が暴 走するためと考えられる. 繊維温度が $823 \mathrm{~K}$ を越えると, $\mathrm{PCS}$ 繊維から $\mathrm{CH}_{4}$ が発生するようになる13). $\mathrm{H}_{2}$ の酸化 のみならず $\mathrm{CH}_{4}$ の燃焼も進行し, 更に繊維温度が高くな り，遂には固体成分が燃焼するようになる。なお，るつぼ に装入する PCS 緎維の量が多い場合には, 熱の放散が不 十分になり，温度の暴走を招きやすかった。

\section{5. 結 論}

実験室的に溶融紡糸して得た PCS 瀻維の熱酸化不融化 速度を熱天秤で測定するとともに, 繊維中への酸素の浸透 状況についても観察した. 不融化速度に及ぼす温度, 酸素 分圧及び繊維径の影響について調べ, 反応機構について検 討した．得られた結果は以下のとおりである.

（1）高温であるほど不融化速度が大きくなるが，463 $\mathrm{K}$ 以上になると繊維の融着が起こる.

（2）雾囲気の $p_{\mathrm{O}_{2}}$ が高くなると，不融化速度が大きく なる. $p_{\mathrm{O}_{2}}$ が限界值を越えると，緎維の融着が起こる．こ の限界值は繊維径が細くなると小さくなる.

（3）繊維径が細くなると，不融化が促進される. 更に 細くなると, 繊維の融着あるいは燃焼が起こる.

（4）緎維中への酸素の浸透は表面から中心へ向かって 同心円状に進行する.

（5）本実験の時間内では不融化速度は 2 次元界面反応 律速式によって処理できた. 見掛けの活性化エネルギーと して $87.7 \mathrm{~kJ} / \mathrm{mol}$ が得られた. 速度定数 $k^{\prime \prime}$ は $p_{\mathrm{O}_{2}}$ に比例し,
また繊維径にほぼ逆比例した。

（6） PCS 繊維の不融化は既反応層を拡散してきた酸素 が未反応の PCS を酸化する界面反応速度によって支配さ れていると推定した. 反応が更に進行して不融化層が厚く なると，この層を通しての酸素の拡散過程へと律速段階が 変化すると考えられる.

\section{文献}

1) Y. Sasaki, Y. Nishina, M. Sato and K. Okamura, J. Mater. Sci., 22, 443-48 (1987).

2) D. J. Pysher, K. C. Goretta, R. S. Hodder, Jr. and R. E. Tressler, J. Am. Ceram. Soc., 72, 284-88 (1989).

3）下尾聰夫, 杉本雅樹, 岡村清人, 日本金属学会誌, 54, 802-08 (1990).

4）下尾聰夫, 杉本雅樹, 岡村清人, セラミックス論文誌， 98, 1324-29 (1990).

5）下尾聰夫, 筧 芳治, 杉本雅樹, 岡村清人, 日本金属学会 誌, 55, 294-303 (1991).

6）下尾聰夫, 筧 芳治, 杉本雅樹, 岡村清人, セラミックス 論文誌, 99, 401-06 (1991).

7) S. Yajima, Am Ceram. Soc. Bull., 62, 893-98 (1983).

8) S. Yajima, Y. Hasegawa, J. Hayashi and M. Iimura, $J$. Mater. Sci., 13, 2569-76 (1978).

9) Y. Hasegawa and K. Okamura, J. Mater. Sci., 18, 3633-48 (1983).

10) Y. Hasegawa and K. Okamura, J. Mater. Sci., 21, 321-28 (1986).

11）長谷川良雄，岡村清人，日化，564-71 (1985).

12) 市川 宏, 寺西春夫, 石川敏功, 日化, 696-704 (1987).

13) Y. Hasegawa, J. Mater. Sci., 24, 1177-90 (1989).

14）下尾聰夫，杉本雅樹，岡村清人，粉体と粉末冶金，37, 1132-37 (1990).

15) J. Szekely, "Rate Phenomena in Process Metallurgy", Wiley-Interscience, New York (1971) p. 369.

16) 橋本栄久, 化学総説, No. 9, 215 (1975).

17）日本化学会編, “化学便覧基礎編 II", 丸善（1975） pp. 1007-115. 